\title{
Weathered rock characterization using drilling parameters
}

\author{
J. Sugawara, Z.Q. Yue, L.G. Tham, K.T. Law, and C.F. Lee
}

\begin{abstract}
The characterization of weathered rocks by the use of drilling parameters is presented. Drilling parameters obtained from the drilling process monitoring system during the installation of soil nails into weathered rocks are used in this investigation. A new drilling index Pi, simplified from the concept of the specific energy, is used in an altempt to differentiate weathered rocks. With Pi or the penetration rate, boundaries of weathered rocks between (1) soil and rock ranges, and (2) grade II and grade III rocks in accordance with the six-fold rock material decomposition grade are identified. For weathered rocks in the soil range, quantitative characterization has been established in this study by using the drilling parameters. An empirical equation has been established for estimating the standiard penctration resistance $N$ value from the drilling parameter $\mathrm{Pi}$, which is used in turn to determine the Mohr-Coulomb friction angle based on the work of Schmertmann. Although this approach tends to yield a slightly larger Mohr-Coulomb friction angle than that from laboratory tests, results obtained in this attempt reveal that estimation of the Mohr-Coulomb friction angle from drilling parameters is attainable with reasonable accuracy.
\end{abstract}

Key words : drilling, standard penetration, percussion index, penetration rate.

Résumé : On présente la caractérisation des roches altérées au moyen des paramètres de forage. On a utilisé dans cette étude les paramètres de forage obtenus par le système de mesure durant le processus de forage de clous dans les roches altérées. On a utilisé un nouvel indice de forage Pi simplifié en partant du concept d'énergie spécificque pour essayer de différencier les roches altérées. Avec Pi ou le taux de pénétration, on identifie les frontières des roches altérées entre (1) les plages de sol et de roc, et (2) le grade II et le grade III des roches d'après le grade à six volets de décomposition du matériau rocheux. Pour les roches altérées dans la plage des sols, on a établi dans cette étude une caractérisation quantitative au moyen des paramètres de forage. On a défini une équation empirique pour estimer la valeur $N$ de la résistance à la pénétration standard en partant du paramètre de forage Pi qui est utilisé à son tour pour déterminer l'angle de frottement Mohr-Coulomb basé sur le travail de Schmertmann. Quoicue cette approche tend à donner un angle de frottement Mohr-Coulomb légèrement plus grand que celui obtenu par les essais de laboratoirc, les résultats obtenus dans cette approche révèle que l'estimation de l'angle de frottement Mohr-Coulomb venant des paramètres de forage peut être atteinte avec une précision raisonnable.

Mots clés : forage, pénétration standard, indice de percussion, taux de pénétration.

[Traduit par la Rédaction]

\section{Introduction}

The geotechnical characteristics of weathered rocks are usually obtained from site investigations and laboratory tests. The characteristics of weathered rocks are distinctively different from those of transported soils and, depending on

Received 30 May 2002. Accepted 15 December 2002.

Published on the NRC Research Press Web site at http://cgj.nre.ca on 21 May 2003.

J. Sugawara, Z.Q. Yue, L.G. Tham, and C.F. Lee. ${ }^{1}$ Department of Civil Engineering, The University of Hong Kong, Pokfulam Road, Hong Kong, China.

K.T. Law. Department of Civil and Environmental Engineering, Carleton University, 1125 Colonel By Drive, Ottawa, ON KIS 5B6, Canada.

'Corresponding author (e-mail: leecf@hkucc.hku.hk). the degree of decomposition, they behave more as rocks of as soils. They are generally less amenable to conventional in situ tests than transported soils because of the presence of corestones and boulders in the decomposed matrix. Furthermore, laboratory tests on them may underestimate their strength since samples free of large particles and boulders are typically used for the testing.

In geotechnical enginecring, drilling is one of the most common and important works in applications such as ground investigation, bored piles, driven piles, soil nailing, raking drains, rock bolts, ground anchors, and so forth. In reference to the works done by Paone el al. (1969), Schmidt (1974), and Tandanand and Unger (1975), a term, specific energy, SE, for percussive drilling is empirically expressed as

[1] $\quad \mathrm{SE}=\frac{4 \mathrm{Tr} \cdot \mathrm{Po}}{\pi d^{2} \cdot \mathrm{PR}}$ 
where Po is the power output of the drilling system, $d$ is the diameter of the bit, $\mathrm{PR}$ is the penetration rate, and $\mathrm{Tr}$ is the transfer coefficient $(=0.7)$. So far, however, most of these studies have been limited within the rock range, especially when pneumatic down-the-hole (DTH) drilling is employed.

This paper investigates the characterization of weathered rocks using the pneumatic DTH drilling parameters. This investigation is not intended to replace any conventional in situ or laboratory tests, but to provide additional useful information with respect to conventional geotechnical practices. Drilling parameters monitored by the drilling process monitoring (DPM) system during the installation of soil nails are used in the investigation. A new drilling index, simplified from the concept of the specific energy, is used to differentiate weathered rocks in accordance with the degree of decomposition of the rock material. An empirical cquation is established for estimating the standard penetration resistance, $N$, which is used in turn to determine the Mohr-Coulomb friction angle of weathered rocks based on the work of Schmertmann (1975).

\section{Outline of drilling process monitoring system}

The DPM system is a portable system that can automatically monitor drilling parameters of pneumatic DTH drills without any adverse affect on the drilling. Installation, disassembling, and operation of DPM are simple tasks. The entire system is operated with only one 12 -volt battery. The DPM consists of a sensor unit and a data processing unit (Fig. 1). The sensor unit includes (1) pressure sensors that measure the working air pressures of the thrust, rotation, and percussion movements; (2) a rotation sensor that measures the rotation speed of the drill rods; and (3) a position sensor that measures the position of the drilling rig on the chain feed. The position sensor takes the initial position of the drill rig as a datum of measurement. Its interpreted data reveals the penetration depth and the penetration rate.

\section{Field testing program}

To characterize weathered rocks by drilling parameters, four field tests of monitored drilling have been carried out with the DPM at four weathered rock sites. Table I summarizes the details of four field tests carried out in this study. All of the drilling monitored in the present study was carried out with conventional pneumatic DTH drills. An inspection, conducted before the testing, confirmed that the button bits used were in the working range according to the Australian Drilling Industry Training Committee Limited (1996). The drilling parameters were acquired by the DPM every second.

Figure 2 shows an example of the data obtained from site A. The data includes position movement of the drill rig on its platform and the pressures for percussive, rotation, and thrust actions with respect to time. This figure covers an entire drilling operation from the beginning of the operation to the extraction of the extension rods after the completion of the hole. Data in this figure present the history of the drilling operation. The following points can be identified:

(1) The operation employed 15 extension rods including the DTH hammer.
Fig. 1. Schematic diagram of DPM.

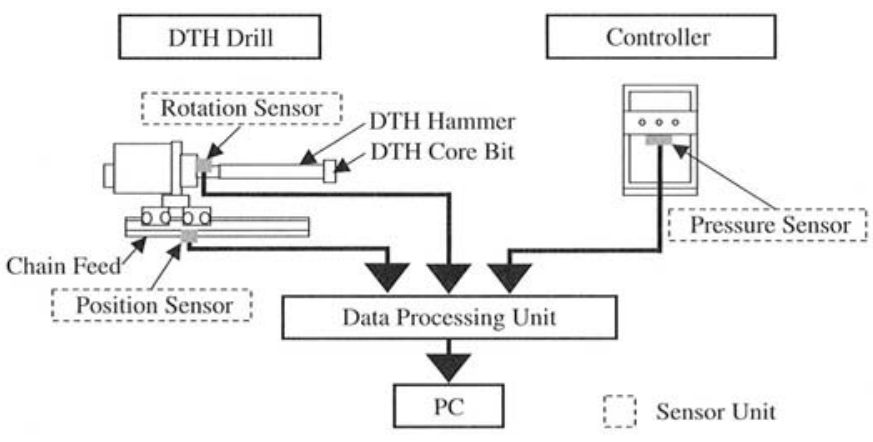

(2) The total construction time was about $53 \mathrm{~min}$. It took approximately $42 \mathrm{~min}$ to form the soil nail hole and then it took $11 \mathrm{~min}$ to retrieve the extension rods from the hole.

(3) Once the material was penetrated, a nearly constant percussion pressure of $1050 \mathrm{kPa}$ and a rotation pressure of $900 \mathrm{kPa}$ were applied. On the other hand, because of frequent back and forth movements of the drill rods to clear the debris from the bottom of the hole, the thrust pressure fluctuated in a range of less than $600 \mathrm{kPa}$.

(4) The penetration rate, represented by the slope of the position-time curve, started to drop at about $26 \mathrm{~min}$ after the start of the drilling process and reached a distinctly slow value after 29 min up until the completion of the hole formation at about $42 \mathrm{~min}$. As the magnitude of the pressures applied in this period of slow penetration rate was not distinctively different from other periods, it is inferred that the operation encountered a harder layer at this stage.

(5) During this period of slow penetration rate, the drill rig moved back and forth only a few times in the drilling operation.

By utilizing these factual data, additional useful information can be obtained. For example, the data can be used for accurate measurements of the drilling depth, determination of basic geotechnical parameters, and so forth.

Figure 3 shows the variation of penetration depth with time in the weathered granite (site A) and weathered tuff (site B) with respect to time. The data for site $\mathrm{A}$ is associated with the factual data shown in Fig. 2. It can be seen that the drill encountered a harder layer at the penetration depth of $12.8 \mathrm{~m}$ at site $A$ and $14.6 \mathrm{~m}$ at site $B$. In addition, the slow penetration rate between 2.7 and $3.1 \mathrm{~m}$ at site $B$ may have been caused by a $0.4 \mathrm{~m}$-size boulder. It is known that unweathered tuff is usually harder than granite. Results therefore indicate that the drilling operation at site $B$ was perhaps completed in the decomposed tuff region before reaching the unweathered tuff zone.

\section{Percussion index}

When the specific energy is compared within similar configurations of DTH drill units, the expression of the specific energy may be simplified without compromising its original concept. The holes for the installation of soil nails in Hong Kong, for instance, are typically between 90 and $110 \mathrm{~mm}$ in diameter and DTH drills used in their operations are almost 
Table 1. Summary of site conditions and field tests.

\begin{tabular}{|c|c|c|c|c|c|c|c|c|c|}
\hline Site & Main formation & $\begin{array}{l}\text { Max. } \\
\text { slope height } \\
\text { (m) }\end{array}$ & $\begin{array}{l}\text { Slope } \\
\text { length } \\
(\mathrm{m})\end{array}$ & $\begin{array}{l}\text { Slope } \\
\text { angle } \\
\left({ }^{\circ}\right)\end{array}$ & $\begin{array}{l}\text { Number } \\
\text { of holes } \\
\text { drilled }\end{array}$ & $\begin{array}{l}\text { Hole } \\
\text { depth } \\
(\mathrm{m})\end{array}$ & $\begin{array}{l}\text { Hole } \\
\text { diameter } \\
(\mathrm{mm})\end{array}$ & $\begin{array}{l}\text { Hole inclination } \\
\text { from the } \\
\text { horizontal }\left({ }^{\circ}\right)\end{array}$ & $\begin{array}{l}\text { Number of } \\
\text { holes } \\
\text { monitored }\end{array}$ \\
\hline A & $\begin{array}{l}\text { Soil and rock (decomposed } \\
\text { granite) }\end{array}$ & 43 & 140 & $50-60$ & $\sim 600$ & $8-20$ & 120 & 10 & $\sim 140$ \\
\hline B & $\begin{array}{l}\text { Soil and rock (debris flow } \\
\text { deposit and decomposed } \\
\text { volcanic) }\end{array}$ & 48 & 175 & 47 & 10 & $4-25$ & 110 & 90 & 7 \\
\hline $\mathrm{C}$ & $\begin{array}{l}\text { Soil and rock (debris flow } \\
\text { deposit and decomposed } \\
\text { granite) }\end{array}$ & 34 & 55 & $\sim 50$ & $\sim 230$ & $10-20$ & 100 & 15 & 3 \\
\hline $\mathrm{D}$ & $\begin{array}{l}\text { Soil and rock (fill } \\
\text { material-colluvium and } \\
\text { decomposed granite) }\end{array}$ & 40 & 200 & $\sim 70$ & 10 & $6-21$ & 100 & 90 & 5 \\
\hline
\end{tabular}

Fig. 2. Example of factual data obtained from DPM.

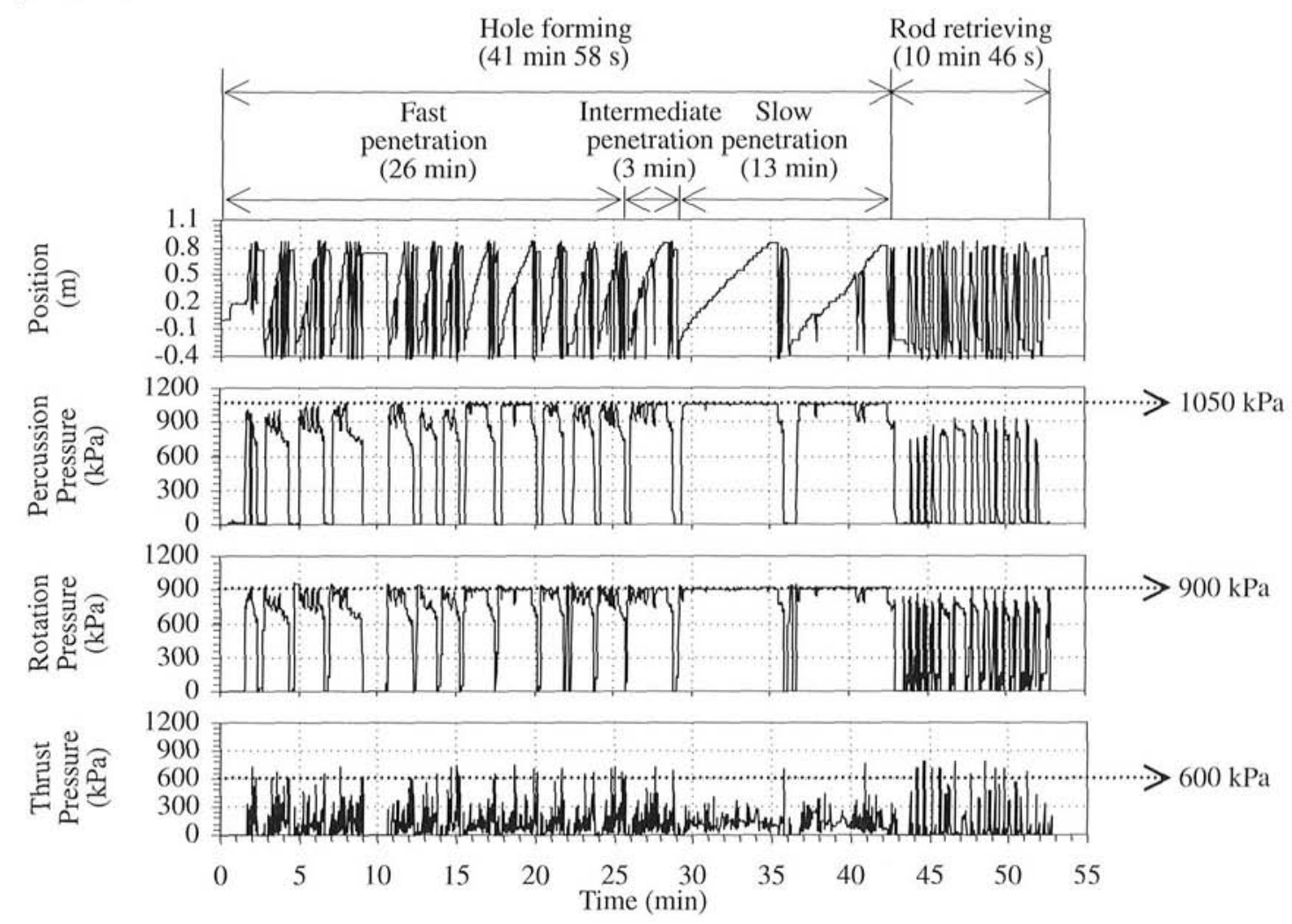

completely standardized in practice. In this study, based on eq. [1], a new drilling index, named the percussion index, $\mathrm{Pi}$, for such applications is proposed as follows:

[2] $\mathrm{Pi}=\frac{\mathrm{PP}}{\mathrm{PR}}\left(\frac{d}{100}\right)^{1.5}$

where PP is the percussion pressure ( $\mathrm{kPa}$ ), PR is the penetration rate $(\mathrm{m} / \mathrm{min})$, and $d$ is the diameter of the bit $(\mathrm{mm})$.

In the above equation, the penetration rate is normalized to a reference DTH bit diameter of $100 \mathrm{~mm}$. The normalization is based on the work of Jimeno et al. (1995) and adopted here in the form of the factor $(d / 100)^{1.5}$. Also it should be pointed out that the energy transfer coefficient $\mathrm{Tr}$ of 1.0 was chosen in the expression of Pi for its simplicity. Accurate evaluation of $\mathrm{Tr}$ is not feasible to date because of its complexity involving a large number of variables. In addition, the operating pressure for percussive action is used as an alternative to the power output of the drilling system since the effect of hammer geometry on the power output is considerably small among similar DTH drill configurations. The pressures for rotary and thrust actions are not considered in this expression, as the DTH drill is primarily a percussion tool, and rotary and thrust actions do not have a decisive influence on penetration rates (Jimeno et al. 1995).

The authors acknowledge that the parameter Pi developed in this study is not an intrinsic geomaterial property but varies with the method of drilling and the types of machincs 
Fig. 3. Variation of penetration depth in $(a)$ weathered granite and $(b)$ weathered tuff with respect to time.

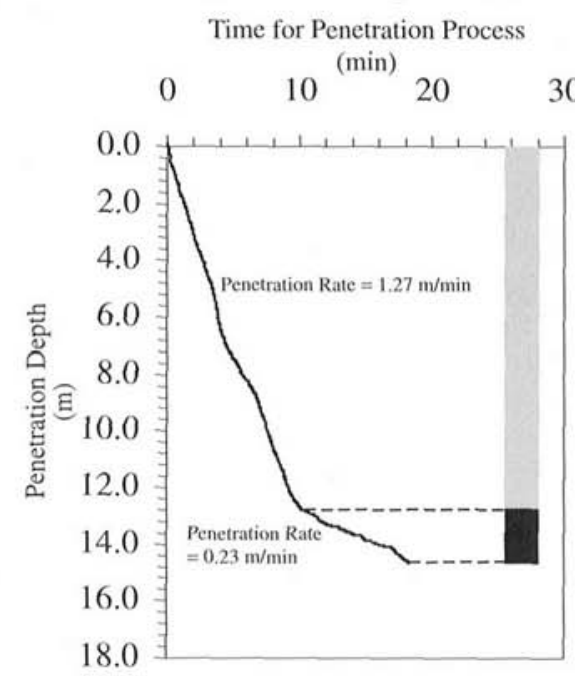

(a)

used. However, for the DTH drilling, which uses bit diameters ranging from 90 to $110 \mathrm{~mm}$ in this study, the use of $\mathrm{Pi}$ is effective without compromising the concept of the specific energy and is a useful guide for the quick assessment of geomaterial characteristics.

\section{Weathered rock differentiation using drilling parameters}

Weathered rocks bchave as rocks or soils, depending on their degree of decomposition. With the penetration rate and $\mathrm{Pi}$, attempts to distinguish weathered rocks have been made in this study with the objective of studying boundaries between (1) soil and rock ranges, and (2) grade II (slightly decomposed) and grade III (moderately decomposed) rocks in accordance with the six-fold rock material decomposition grade, which has been recommended for various engineering purposes by many international and local engineering bodies (c.g., ISRM 1978; IAEG 1981; BSI 1981; GEO 1988). A general description of the decomposition grades of igneous and volcanic rock materials is given in Table 2 .

The value of $\mathrm{Pi}$ for different decomposition grades of rocks has been determined to differentiate weathered rocks, based on pneumatic DTH drilling parameters monitored by DPM at the four different sites summarized in Table 1. The decomposition grade of each data point, based on the qualilative description as given in Table 2, was obtained from ground investigations previously conducted as part of slope upgrading works.

Figure 4 shows relationships of the rock material decomposition grade to the penetration rate and $\mathrm{Pi}$. The penetration rate appeared to increase with an increase in the decomposition grade, while $\mathrm{Pi}$ decreased with an increase in the decomposition grade, particularly in the rock range where $\mathrm{Pi}$ values were above 1500 . On the contrary, the penetration rate and $\mathrm{Pi}$ values in the soil range were found to have no distinctive relationship with decomposition grades. From this observation, it is possible to interpret weathered granitic rocks as shown in Table 3.
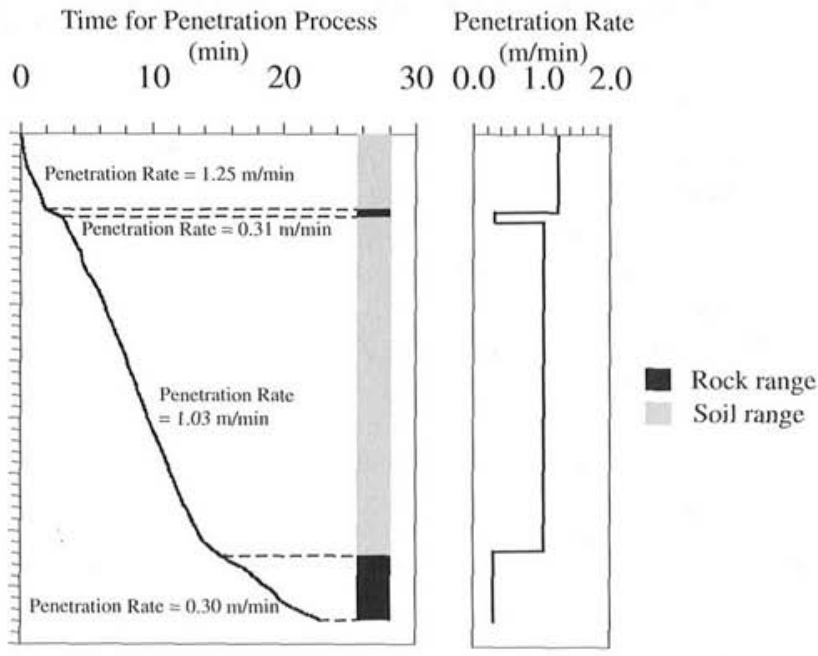

(b)

The penetration rate of $0.7 \mathrm{~m} / \mathrm{min}$ or a $\mathrm{Pi}$ value of 1500 can be chosen as the boundary for separating soil from rock for materials deriving from granitic rocks. Furthermore, the penctration rate of $0.4 \mathrm{~m} / \mathrm{min}$ or $\mathrm{Pj}$ of 2600 appears to be appropriate to separate grade II and grade III granitic materials. Apart from the transition section between grade II and grade III shown as II/III in the figure, most of the data obtained from similar DTH drills concur with these differentiations. In the soil range however, differentiation between grade IV and grade $V$ was found to be difficult with the use of drilling parameters alone. This can be explained by the fact that the degree of decomposition in the soil range, as shown in Table 2, is based on qualitative description. Overlapping between grades is common in the field, and therefore differentiation between grade IV and grade $V$ is sometimes not elear-cut. In reality, the differentiation between these two grades depends on such factors as moisture content, stress level, in situ density, and so forth, which are themselves a function of soil mass strength playing important roles.

There is another system of classifying weathered rocks based on a quantitative approach by means of the Schmidt hammer rebound number, $\mathrm{Rn}$. This number can be obtained directly (GEO 1988). It was also found indirectly by Kahraman (1999) who proposed the following empirical relationship between the Schmidt hammer rebound number and the penctration rate for DTH drills:

[3] $\quad \mathrm{PR}=3.24 \frac{(\mathrm{PP} \cdot \mathrm{d} p)^{0.826}}{\mathrm{Rn}^{1.900}}$

where PP is the percussion pressure (bar), PR is the penetration rate $(\mathrm{m} / \mathrm{min})$, and $\mathrm{d} p$ is the diameter of the piston $(\mathrm{mm})$. By substituting eq. 13] into eq. [2], the following now equattion can be obtained:

$$
\mathrm{Pi}=\frac{1}{71.42} \frac{\mathrm{Rn}^{1.900} \mathrm{PP}^{0.174} d^{1.500}}{\mathrm{~d} p^{0.826}}
$$

where PP is now in kPa. If a piston diameter of $63 \mathrm{~mm}$ is estimated to be the normal diameter for the typical size of 
Table 2. General description of decomposition grades of igneous and volcanic rock materials (after GEO 1988).

\begin{tabular}{|c|c|c|}
\hline Decomposition term & Grade symbol & Typical characteristics \\
\hline Residual soil & VI & $\begin{array}{l}\text { Original rock texture completely destroyed; can be crumbled by hand and finger pressure } \\
\text { into constituent grains }\end{array}$ \\
\hline Completely decomposed & V & $\begin{array}{l}\text { Original rock texture preserved; can be crumbled by hand and finger pressure into constit- } \\
\text { uent grains; easily indented by point of geological pick; slakes in water; completely } \\
\text { discoloured compared with fresh rock }\end{array}$ \\
\hline Highly decomposed & IV & $\begin{array}{l}\text { Can be broken by hand into smaller pieces; makes a dull sound when struck by hammer; } \\
\text { not easily indented by point of pick; does not slake in water; completely discoloured } \\
\text { compared with fresh rock }\end{array}$ \\
\hline Moderately decomposed & III & $\begin{array}{l}\text { Cannot usually be broken by hand; easily broken by hammer; makes a dull or slight } \\
\text { ringing sound when struck by hammer; completely stained throughout }\end{array}$ \\
\hline Slightly decomposed & II & $\begin{array}{l}\text { Not broken easily by hammer; makes a ringing sound when struck by hammer; fresh rock } \\
\text { colours generally retained but stained near joint surfaces }\end{array}$ \\
\hline Fresh rock & I & $\begin{array}{l}\text { Not broken easily by hammer; makes a ringing sound when struck by hammer; no visible } \\
\text { signs of decomposition (i.e., no discolouration) }\end{array}$ \\
\hline
\end{tabular}

Note: In general practice, grade III or lower materials are considered rock and grade IV or higher materials are considered soil.

Fig. 4. Relations between rock material decomposition and $(a)$ penetration rate and $(b) \mathrm{Pi}$.

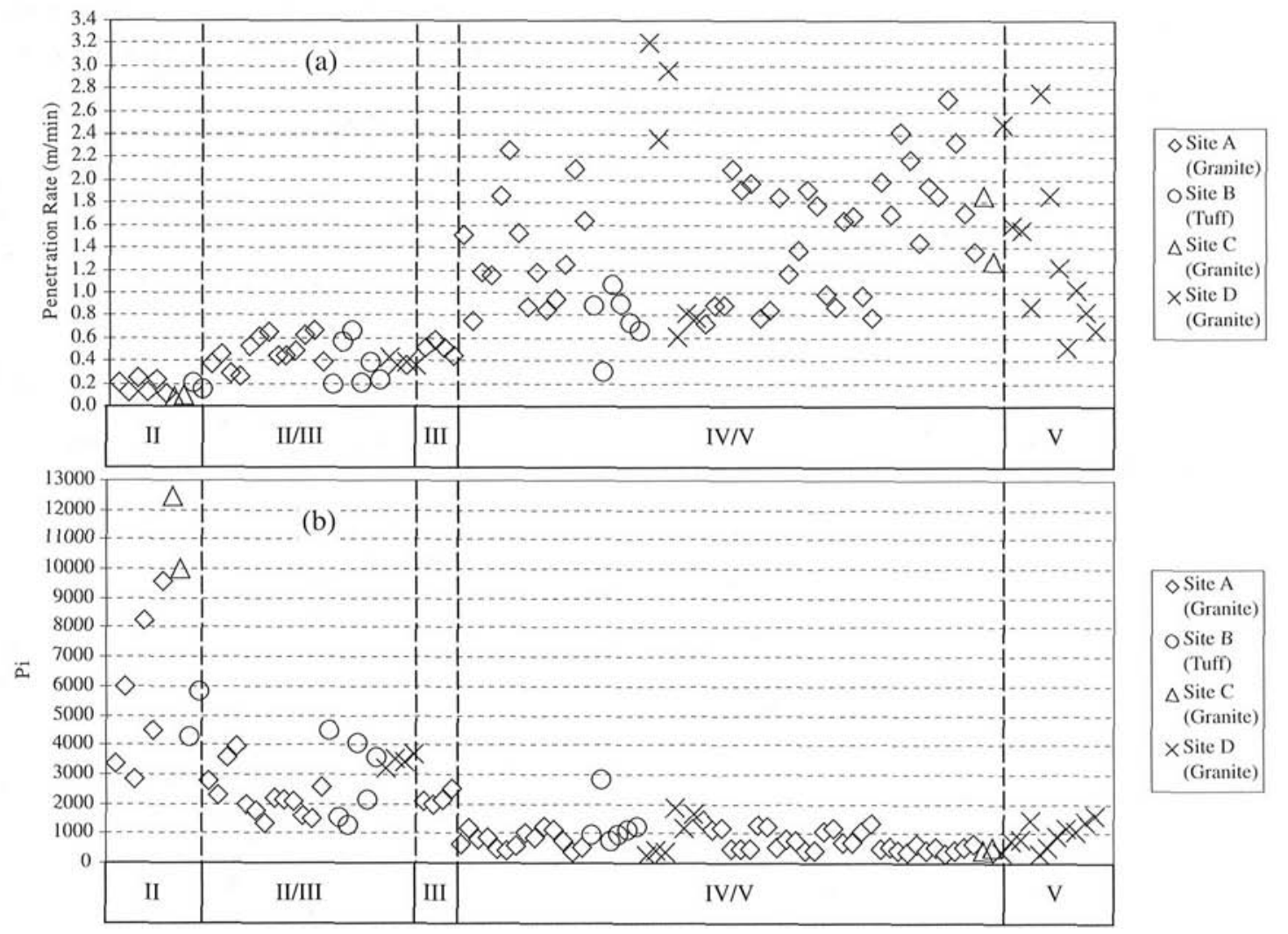

Table 3. Differentiation of weathered granitic rocks based on penetration rate or $\mathrm{Pi}$.

\begin{tabular}{lll}
\hline Grade & Penetration rate $(\mathrm{m} / \mathrm{min})$ & $\mathrm{Pi}$ \\
\hline Grade II & $<0.4$ & $>2600$ \\
Grade III & $0.4-0.7$ & $1500-2600$ \\
Grade IV or higher & $>0.7$ & $<1500$ \\
\hline
\end{tabular}

$100 \mathrm{~mm}$ diameter for soil nail holes, the following approximate relationship can be obtained under the usual operating conditions:
$|5|$

$$
\mathrm{Pi}=1.52(\mathrm{Rn})^{1.900}
$$

For grade III material (rock), the $\mathrm{Pi}$ value ranges from 1500 to 2600 as shown in Table 3. The corresponding Schmidt hammer rebound numbers have been calculated to be 37 and 50, respectively. The classification on the degree of decomposition based on this indirect determination of $\mathrm{Rn}$ is shown in Table 4 . In this table, the $R n$ values based on direct determination used by GEO (1988) are also shown. These $\mathrm{Rn}$ values determined with $\mathrm{Pi}$, in particular $\mathrm{Rn}=37$ for separating soil from rock, were found to be higher than those suggested by the GEO system. This is understandable 
Table 4. Comparison of Schmidt hammer rebound number estimated from $\mathrm{Pi}$ and obtained from GEO (1988).

\begin{tabular}{lll}
\hline Decomposition (granite) & $\begin{array}{l}\text { Schmidt hammer rebound } \\
\text { number estimated from Pi }\end{array}$ & $\begin{array}{l}\text { Schmidt hammer rebound number } \\
\text { obtained from GEO (1988) }\end{array}$ \\
\hline Highly decomposed & $<37$ & $<25$ \\
Moderately decomposed & $37-50$ & $25-45$ \\
Slightly decomposed & $>50$ & $>45$ \\
\hline
\end{tabular}

because the determinations of $\mathrm{Rn}$ in the present study and in the GEO system are entirely different. When drilling parameters expressed in terms of the Schmidt hammer rebound number are used to separate (1) soil from rock for materials deriving from granitic rocks and (2) grade II and grade III granitic rocks, the proposed criteria in column (2) of Table 4 should be used.

\section{Soil parameter assessment using drilling parameters}

\section{Standard penetration resistance assessment using drilling parameters}

It appears that some attempts (e.g., Nishi et al. 1998; Gui et al. 1999) have been made to utilize drilling parameters for the investigation of soil characteristics. One of the reasons that this approach has drawn relatively little attention is perhaps due to the fact that soil characterization requires a considerably larger number of parameters than rock characterization.

In view of this fact, one possible way of using drilling parameters for the characterization of "soil-like" weathered rocks may be to refer to the standard penetration resistance, $N$. Similar to the $N$ value, $\mathrm{Pi}$ is expected to vary with the strength and integrity of the geomaterials.

Figure 5 shows the relationship between $\mathrm{Pi}$ and the $N$ value for weathered granitic rocks based on data obtained at sites $A, C$, and D with granites weathered to various degrees. The $N$ values were obtained from previously conducted ground investigations at these sites. Since the $\mathrm{Pi}$ and the $N$ values are functions of ground resistance, a linear trend therefore emerges between these two quantities, as shown in Fig. 5. Some data scatter is expected with the relatively inexact nature of obtaining the $\mathrm{Pi}$ and $N$ values. For the DTH drilling, using bit diameters ranging from 90 to $110 \mathrm{~mm}$, regression analysis of the data gives the following empirical equation:

$$
\text { [6] } \mathrm{Pi}=75 \mathrm{~N}
$$

The above equation linking $\mathrm{Pi}$ with $N$ constitutes a very efficient tool for estimating the $N$ value from the drilling parameter Pi. Another advantage of the technique proposed here is that it can give a continuous indication of delicate change in weathered rocks, which might be overlooked in standard penetration tests (SPT) because of its discrete nature of measurement.

\section{Mohr-Coulomb friction angle assessment using drilling parameters \\ The Mohr-Coulomb friction angle of weathered rocks is usually determined in the laboratory using materials fiec}

from large particles and boulders. However, this approach is typically very time-consuming and costly. An alternative approach using the drilling parameters may be possible to obtain the approximate value of the friction angle of weathered granitic rocks.

The new approach is based on the empirical relationship of eq. [6] in this paper and the work published by Schmertmann (1975), which correlates the Mohr-Coulomb friction angle to the $N$ value and the effective overburden pressure. With $N$ now related to $\mathrm{Pi}$, one can relate $\mathrm{Pi}$ to the friction angle via Schmertmann's work.

Table 5 compares the Mohr-Coulomb friction angles of weathered granitic rocks from sites A, C, and D obtained using this approach and those determined by conventional undrained triaxial compression tests. The data points were chosen from the locations where the soil parameters are known from laboratory tests. The effective overburden pressures of each data point were calculated in accordance with the unit weight obtained from the previously conducted laboratory test. The comparison suggests that an approximate estimation of the Mohr-Coulomb friction angle of weathered rocks from $\mathrm{Pi}$ is possible with reasonable accuracy, although this approach tends to yield larger friction angles than those from laboratory tests. It is known that the Mohr-Coulomb friction angle derived from Schmertmann's empirical relationship may be in error by up to $\pm 5^{\circ}$ because of scatter in the original database and inaccuracies in the SPT (GEO 1993). The error found in this study may also be explained by the same reason as well as by an interlocking of weathered rock grains.

An interlocking of grains, known as bonding, influences the strength and stiffness of weathered rocks and gives an appreciable cohesion value. Particularly when the overburden pressure is small, the presence of the Mohr-Coulomb cohesion reduces the angle of the failure envelope in the Mohr diagram, while this influence may be negligible at high effective overburden pressures. Theoretically, the influence of bonding on the Mohr-Coulomb friction angle should be large at less weathered stages, i.e., at larger Pi values. However, this phenomenon was not clearly observed in this study because of the limited number of data available. More work needs to be done on this aspect.

Another possible reason why the empirical approach introduced in this paper tends to yield higher Mohr-Coulomb friction angles than the laboratory values is perhaps due to the fact that laboratory samples are normally free of large particles and boulders, although these may be still amenable to the SPT in the field. The laboratory test may therefore yield underestimated strength compared with the in situ value.

The empirical approach presented in this paper permits the cstimation of an approximate Mohr-Coulomb friction 
Fig. 5. Relationship between $\mathrm{Pi}$ and $N$ value.

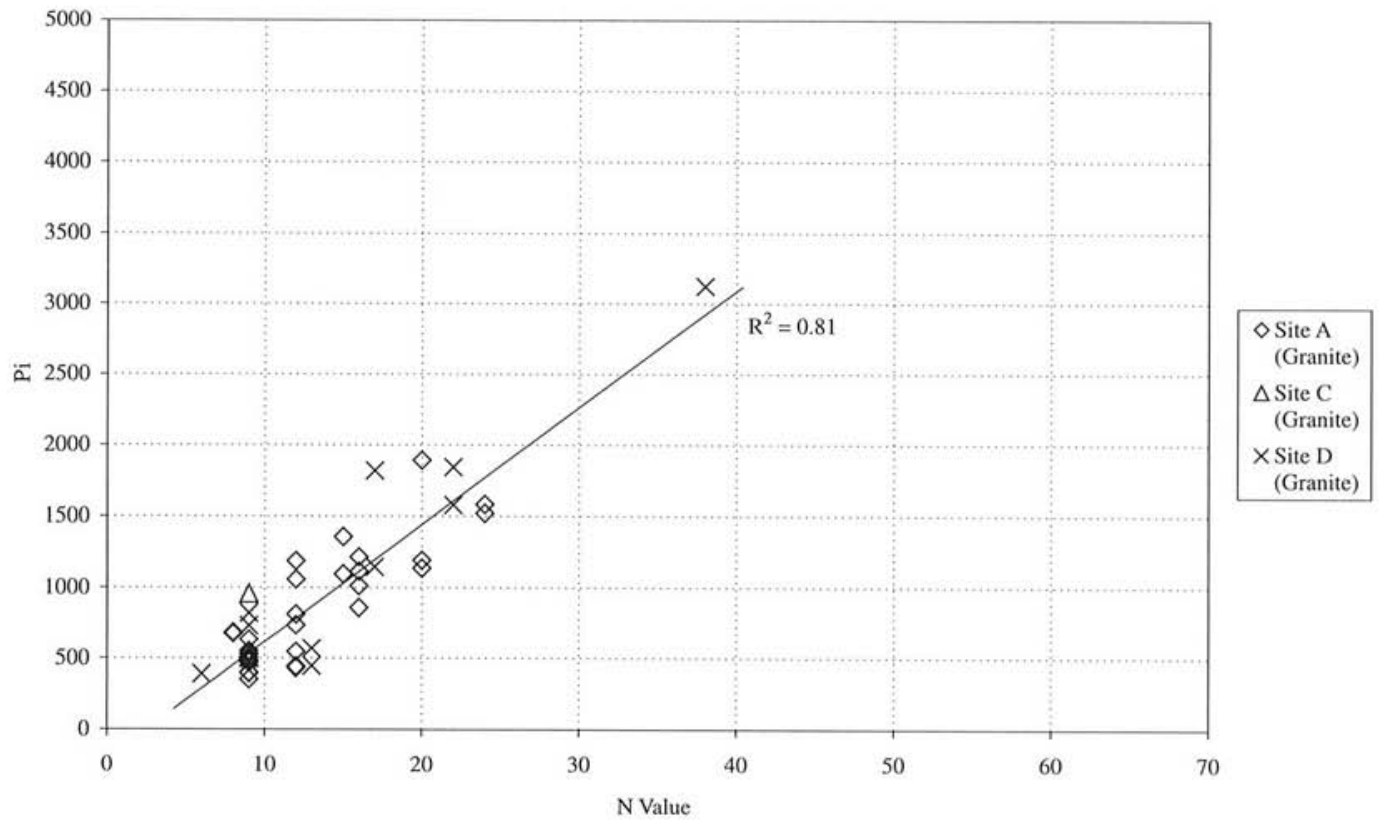

Table 5. Comparison of Mohr-Coulomb friction angles obtained from $\mathrm{Pi}\left(\phi_{(\mathrm{Pi})}^{\prime}\right)$ and laboratory tests $\left(\phi_{(\mathrm{Lab})}^{\prime}\right)$.

\begin{tabular}{|c|c|c|c|c|c|c|}
\hline Sample & $\begin{array}{l}\text { Effective } \\
\text { overburden } \\
\text { pressure }(\mathrm{kPa})\end{array}$ & $\mathrm{Pi}$ & $\begin{array}{l}\text { SPT } N \\
\text { obtained } \\
\text { from } \mathrm{Pi}\end{array}$ & $\phi_{(\mathrm{Pi})}^{\prime}\left({ }^{\circ}\right)$ & $\phi_{\text {(Lab) }}^{\prime}\left({ }^{\circ}\right)$ & $\phi_{(\mathrm{Pi})}^{\prime}-\phi_{(\mathrm{Lab})}^{\prime}\left({ }^{\circ}\right)$ \\
\hline 1 & 32.11 & 687.57 & 9 & 39.0 & 31.0 & 8.0 \\
\hline 2 & 32.11 & 679.09 & 9 & 39.0 & 31.0 & 8.0 \\
\hline 3 & 80.28 & 472.23 & 6 & 32.0 & 32.1 & -0.1 \\
\hline 4 & 80.28 & 505.70 & 7 & 33.0 & 32.1 & 0.9 \\
\hline 5 & 80.28 & 484.14 & 6 & 32.0 & 32.1 & -0.1 \\
\hline 6 & 125.77 & 1136.58 & 15 & 37.5 & 33.3 & 4.2 \\
\hline 7 & 125.77 & 1191.98 & 16 & 38.0 & 33.3 & 4.7 \\
\hline 8 & 162.17 & 1583.50 & 21 & 39.0 & 37.9 & 1.1 \\
\hline \multirow[t]{2}{*}{9} & 162.77 & 1520.39 & 20 & 38.5 & 37.9 & 0.6 \\
\hline & & & & & Average & 3.0 \\
\hline
\end{tabular}

angle for weathered rocks where drilling work is conducted. It should be noted that great care must be taken with the use of this technique. For instance, unusually high $\mathrm{Pi}$ values, which may occur locally when corestones are encountered, should not be used to avoid an overestimation of the Mohr-Coulomb friction angle for soils.

\section{Conclusions}

A series of investigations using pneumatic DTH drilling parameters for the characterization of weathered rocks has been conducted. The results indicate that identification of boundaries of weathered rocks between soil and rock ranges, and grade II and grade III rocks are attainable based on the penetration rate and a new drilling index $\mathrm{Pi}$. The differentiation of different grades of weathered rocks within the soil range was found to be difficult with the use of drilling parameters alone.
For weathered rocks in the soil range, a quantitative way of characterization based on the drilling parameters has been established in this study. An empirical equation has been established for estimating the $N$ value from the drilling parameter $\mathrm{Pi}$, which is used in turn to determine the Mohr-Coulomb friction angle based on the work of Schmertmann (1975). A comparison of the results obtained from this approach with those obtained using conventional laboratory tests shows reasonably good agreement, suggesting that the Mohr-Coulomb friction angle of weathered granitic rocks can be estimated with the drilling parameters.

\section{Acknowledgement}

The authors wish to acknowledge the financial supports to this research by the Research Grant Council of HKSAR Government (HKU7005/01E RGC) and the Hong Kong Jockey Club Charities Trust. We wish to thank the kind support from Halcrow China Ltd. We also wish to thank 
Mr. T.C. Chan and Mr. C.H. Tse for their technical support with the experimental part of this investigation.

\section{References}

Australian Drilling Industry Training Committee Limited. 1996. Drilling: The manual of methods, applications, and management. 4th ed. Lewis Publishers, Fla.

BSI. 1981. Code of practice for site investigations (BS5930), British Standards Institution (BSI), London, pp. 147.

GEO, 1993. Guide to retaining wall design (GEOGUIDE 1). Gcotechnical Engineering Office, Civil Engineering Department, Hong Kong Government.

GEO. 1988. Guide to rock and soil descriptions (GEOGUIDE 3). Geotechnical Engineering Office, Civil Engineering Department, Hong Kong Government.

Gui, M.W., Soga, K., Bolton, M.D., Hamelin, J.P., Hass, G., Burgess, N., and Butler, A.P. 1999. Instrumented borehole drilling using ENPASOL system. In Proceedings of the 5th International Symposium on Field Measurements in Geomechanics, Singapore, pp. 1-5.

IAEG. 1981. Rock and soil description and classification for engineering geological mapping. Bulletin of the International Association of Engineering Geology, Paris, France. No. 24, pp. 235-274.

ISRM. 1978. Suggested methods for the quantitative description of discontinuities in rock masses. International Society for Rock Mechanics Committee on Laboratory Tests. International Journal of Rock Mechanics and Mining Sciences and Geomechanics Abstracts, 15: 319-368.
Jimeno, C.L., Jimeno, E.L., and Carcedo, F.J.A. 1995. Drilling and blasting of rocks. Geomining, Technological Institute of Spain. A.A. Balkema, Rotterdam.

Kahraman, S. 1999. Rotary and percussive drilling prediction using regression analysis. International Journal of Rock Mechanics and Mining Sciences, 36: 981-989.

Nishi, K., Suzuki, Y., and Sasao, H. 1998. Estimation of soil resistance using rotary percussion drill. In Geotechnical Site Characterization: Proceedings of the 1 st International Conference on Site Characterization -- ISC'98, Allanta, Ga., 19-22 April. Edited by P.K. Robertson and P.W. Mayne. A.A. Balkema, Rotterdam. Vol. 1, pp. 393-398.

Paone, J., Madson, D., and Bruce, W.E. 1969. Drillability studies-laboratory percussive drilling. U.S. Department of Interior, U.S. Bureau of Mines, USBM RI 8073.

Schmertmann, J.H. 1975. Measurement of in situ shear strength. In Proceedings of Conference on In Situ Mcasurement of Soil Properties, North Carolina State University, Raleigh, N.C., 1-4 June. Specialty Conference of the Geotechnical Engineering Division, American Socicty of Civil Engincers, New York. Vol. 2, pp. 57-138.

Schmidt, R.L. 1974. Drillability studies - percussive drilling in the field. U.S. Department of Interior, U.S. Burealu of Mines, USBM RI 7684.

Tandanand, S., and Unger, H.F. 1975. Drillability determinationa drillability index of percussive drills. U.S. Department of Interior, U.S. Bureau of Mines, USBM RI 8073. 